\title{
THE COFFEE MARKET
}

By G. G. Huebner, Рh.D., Instructor in Transportation and Commerce, University of Pennsylvania.

Over $2,300,000,000$ pounds of coffee are annually produced on the plantations of the countries where it is a staple product. About $961,000,000$ pounds are each year consumed in the United States, and in r9Io, 873,983,757 pounds were imported. This places the United States in the forefront of all the coffee markets of the world and has made possible the development of a market as highly organized as those of grain, cotton or any of the great agricultural staples.

\section{Coffee Production and Consumption}

The source of the coffee supply lies in the tropics and is widely scattered. The greatest of all the coffee producers is Brazil, and Brazilian coffee, being of the "strong" variety, is of particular importance to the American consumer with his long nursed taste for that class of table beverage. The Brazilian states of Rio and Sao Paulo have the principal coffee plantations of the entire world. To them coffee means more than does the cotton crop to the American cotton belt. The close dependence of the people upon their single large crop is the chief difficulty which now confronts them. From 9,500,000 bags in 1899-00 the world's crop grew to II,300,000 in $1905-06$ and to $20,000,000$ in 1906-07, with a consequent decline in price and further mortgaging of the coffee plantations of these states.

The State of Sao Paulo in attempting to aid the planters in their difficulty undertook its policy of "coffee valorization," which has since been one of the leading forces in the production of coffee as well as of considerable importance in its distribution to the various coffee markets. Coffee valorization is essentially an attempt to corner the market, and in that way control the price. The State of Rio declining to share the financial risk involved, it was undertaken by Sao Paulo alone. In order to limit the world's supply to $17,000,000$ bags, the state went into the market as a coffee buyer. A tax was placed upon exports and coffee-tree planting, treasury bills were issued, and, with the stored coffee as collateral, loans (6I0) 
were obtained from large banking concerns in New York, London and various European ports. By the end of 1907 the state found itself in financial difficulty with a large amount of coffee on hand, and unable to raise more funds with which to stem the still declining market. In order to refinance its coffee holdings an agreement backed by the federal government of Brazil was made with the syndicate of interested banks. Under this agreement (I) the federal government guarantees a new loan of $£_{15}, 000,000,(2)$ the coffee holdings are stored in warehouses at New York and seven European ports and warrants are deposited with three designated banks as trustees, and (3) the coffee is placed under the control of a committee of seven residents of the United States and Europe. These men may sell the coffee holdings, the minimum annual sales being specified. (4) The surtax is raised from three to five francs per bag, and is used for interest, amortization, etc., of the loan. (5) The total exports are limited to 9,000,000 bags in 1908-9, $9,500,000$ in 1909-10, and 10,000,000 thereafter annually.

During the period of state purchases various effects of the valorization plan became manifest. On the one hand the state government suffered a loss of several millions; and the credit of the state suffered severely. Conversely, however, numerous planters received higher prices than the open market warranted; and prices generally were steadier. The large crop of I906-7 would probably have demoralized the world market had the state been absent as a powerful bull factor. Moreover, the preference of the government for the better grades, also, induced the planters to improve the quality of their output, and in that way exerted a favorable influence upon production. ${ }^{1}$

Since additional purchases have been discontinued the State of Sao Paulo is still a material factor in the production and sale of coffee, in that the surtax on exports still remains, the annual quantity of exports is restricted, there is a tax on the planting of new trees, and a large though declining quantity of coffee lies in the warehouses of the leading coffee markets which, under certain restrictions, can be sold by the trustees in charge. Ordinarily a large known supply of a staple article acts as a weight upon the market, but it has not had that effect upon the price of coffee. This price has been increasing during the last year, and coffee dealers have

${ }^{1}$ Quarterly Journal of Economics, May, 1909. 
explained that any attempt on the part of an importer to seriously interfere with the plan to maintain prices could be crushed by the release of large quantities of the stored coffee. On the other hand the coffee can be safely held, for its quality increases with age.

Though Brazil produces about two-thirds of the world's crop, the valorization plan was hampered by the existence of other sources of supply. The Central American countries, chiefly Guatemala, are an important source; Venezuela, Colombia, the Dutch East Indies, the West Indies, Mexico and various points in Africa produce considerable coffee; and smaller amounts are grown in Ecuador, Arabia and the Philippines.

The following table shows the amounts raised in the leading producing countries in 1909 and the quantities exported to the United States in Igog and I9Io (in thousands of pounds) :

\begin{tabular}{|c|c|c|c|}
\hline \multirow[b]{2}{*}{ Country } & \multirow{2}{*}{$\begin{array}{c}\text { Production in } \\
\text { r909 }\end{array}$} & \multicolumn{2}{|c|}{ Exports to United States } \\
\hline & & 1909 & 1910 \\
\hline Brazil & $1,674,428$ & 818,444 & 699,242 \\
\hline Central America & 164,489 & 40,752 & 30,040 \\
\hline Venezuela .. & I03,454 & 54,774 & 42,542 \\
\hline West Indies & 89,733 & 3.313 & $4,63^{2}$ \\
\hline Colombia & 79,366 & 60,184 & 53,332 \\
\hline Dutch East Indie $3 . .$. & 56,7068 & I 1,387 & II, 354 \\
\hline Mexico $\ldots \ldots \ldots \ldots$ & 42,000 & 35,004 & $2 \mathrm{I}, 205$ \\
\hline Africa $\ldots \ldots$ & $20,45^{2}$ & 17 & 3 \\
\hline Total & $2,230,600$ & $\mathrm{x}, 023,875$ & $862,35^{\circ}$ \\
\hline World's total & $2,367,289$ & $1,051,749$ & 873,984 \\
\hline
\end{tabular}

In the aggregate no country rivals the United States as a coffee-drinking nation. Germany comes nearest with an annual consumption of about $396,205,000$ pounds. The annual per capita consumption of the United States of nearly I4 pounds is, aside from the producing countries, exceeded only in Belgium and Holland. In Germany it is but $6 \frac{1}{2}$ pounds, in France 4.3 , in AustriaHungary 2.05, and in England 69/100 of one pound.

\section{Classification of Coffec}

Many grades and classes of coffee are sold in the American market, and at different points in the course of its sale and by the various parties handling it, it is differently classified. In Brazil coffee is classed primarily as "Rio" and "Santos" coffee, and these (6I2) 
again into "highland" and "lowland." It is then further divided into grades as to its quality, commonly into first, good first, regular first, ordinary first, second, good second and ordinary second.

Importers and roasters also distinguish between coffees as to their source of production. Thus they commonly talk of Rio, Santos, Java, Mocha, Maracaibo, La Guaira, etc., coffee. Java and Mocha, however, have become trade names applied to many kinds of "mild" coffee. Even in the case of coffee legitimately called "Java," the name is a myth, for Java in the blend comes mostly from the island of Sumatra. American coffee dealers, also, commonly classify coffee into grades of quality depending upon the size of the bean, its color, uniformity and cleanliness. Terms such as fancy, prime, good, fair, ordinary and common are used in buying and selling spot coffee.

The most generally applied classification is that of the New York Coffee Exchange, which is used by its members for trading purposes. Its rules divide the green coffee as it is imported into nine grades known as Standard Grades numbers 1 to 9 . The methods of arriving at these grades will be explained later.

\section{The Purchase and Sale of Coffec}

In the bringing of the coffee from the planter to consumer many parties are usually involved. As a rule the green berry passes from the planter of Brazil to the "Commisario" who is a commission man and something more. As the local banker, landlord or country merchant sometimes does in the cotton states, so the commisario lends money to the planters, taking the growing crop as collateral. Later the coffee may be sold to him as a dealer or through him as a commission man, the planter receiving the balance over and above his debts. The commisario may sell the coffee to an exporting concern, and this may sell it to the New York importer. However, the process varies, for some planters sell direct to exporters; and importing firms may have agents to buy direct from the planter or commisario.

The green coffee being purchased by the importers it is traded in at the great coffee markets, the largest of all being New York. Other dealers may intervene, but ultimately the green berries are purchased by "roasting concerns," and the importer may himself be a roaster. Here the coffee is roasted and prepared for the 
grocery market. It may be shipped to wholesale grocers in bulk or in prescribed packages, whole or ground, and special trade names and brands may be attached. The wholesale grocers in all parts of the United States distribute it to the retail merchants.

The New York market receives about ninety-seven per cent. of the annual coffee imports of the United States, and it is here that the best organized coffee market has been established. In the passing of the green coffee from importers to roasters or dealers and brokers, two markets are distinguished. One, the "spot market," is of local significance and is located in the district of lower Wall Street and sections on Water and Front Streets. Here coffee importers, roasters, dealers and brokers conduct their "street sales." Besides these private sales there are the "exchange sales" which are made in the other or "exchange market." This business is conducted on the floor of the "Coffee Exchange of the City of New York."

\section{The Coffee Exchange of the City of New York}

In the fall of 1880 there was a period of two months during which the coffee trade was almost at a complete standstill. There was a large accumulation of coffee in the port warehouses and the traders of the interior were fully supplied. Prices varied between sales as much as three cents per pound or $\$ 4.25$ per bag. The first coffee exchange was then organized at Havre in 1881 , and in the same year the "New York Coffee Exchange" was incorporated. It operated until I885, when its property was by resolution of the governing committee transferred to the present "Coffee Exchange of the City of New York." As stated in its charter its purposes "shall be to provide, regulate and maintain a suitable building, room or rooms for the purchase and sale of coffees and other similar grocery articles in the city of New York, to adjust controversies between members, to inculcate and establish just and equitable principles in the trade, to establish and maintain uniformity in its rules, regulations, and usages, to adopt standards of classification, to acquire, preserve, and disseminate useful and valuable business information, and generally to promote the above mentioned trade in the city of New York, increase its amount, and augment the facilities with which it may be conducted."' p. vi.

${ }^{2}$ Charter, By-Laws and Rules of Coffee Exchange of Cits of New York (1902). 
In the promotion of the trade at New York the exchange has been signally successful, New York having become the greatest coffee market the world over. It has also been successful in organizing the trade on a safe and conservative basis. At first the calls of the exchange were "attended barely by a corporal's guard, many of the larger importing and jobbing houses refusing to join. But in less than a year the raison d'ctre of an exchange in New York becoming evident, nearly a hundred representative houses in the city and abroad that a year before had refused to join at the original initiation fee of $\$ 250$ purchased seats in the exchange at $\$ 500$; and those who did not even then join were glad to come in later at $\$ \mathrm{I}, 000$, at which figure the number was swelled to an even hundred." 3 At a recent date its membership numbered 323 brokers, importers, dealers and roasters. Membership is passed upon by a committee on membership, but any one twenty-one years of age, resident or non-resident, of good character and commercial standing is eligible when proposed as a candidate by one member of the exchange and seconded by another. The membership committee refers the names of applicants with recommendations to the board of managers, where a ballot is taken, one adverse vote in three excluding. Seats sell at $\$ I, 500$ but the exchange holds them at $\$ 10,000$ until there are 350 members of the exchange. Annual assessments are only about thirty dollars per year as the rents of the new building at Hanover Square are nearly sufficient to provide the necessary funds.

The exchange annually elects a president, vice-president and treasurer, who perform the usual duties of exchange officers. The real governing body is the Board of Managers, consisting of the president, vice-president, treasurer and twelve other members. This governing board, meeting monthly, appoints the necessary subordinate officers and employees and fixes their compensation, and may "summon before them any officer or member for any purpose whatsoever." It appoints the secretary of the exchange from among its own number, a superintendent of the exchange, and the numerous committees which are in active charge of specified activities. It also licenses the necessary coffee graders, warehousemen, weighmasters and samplers of the exchange.

A brief discussion of the duties of the superintendent and the aThe Alcolm Magazine, March, 1909, p. 4. 
various committees will help to explain the methods of the exchange market. The superintendent, under the direction of the board of managers, has charge of the details of its work and of that of the various committees. He keeps all the books and documents of the exchange; collects and pays over to the treasurer all moneys due the exchange not otherwise provided for, receives, deposits and pays over all margins on coffee contracts; has active charge of the exchange rooms and the bulletin board; and manages and appoints, with the consent of the board of managers, the assistants needed to perform the details of the work under his charge.

One of the functions of the exchange is that of grading and classifying the coffee, and it has taken steps to fully safeguard this work. As previously stated, the exchange rules provide for nine standard grades, and only licensed graders are permitted to grade coffee traded in on the exchange. At a recent date there were twenty-six licensed graders. One of them is appointed by the board of managers to annually provide fresh standards and "maintain them as nearly as possible on an equality." These selections, when approved by the board, are adopted by the exchange as the basis for the year. Upon receipt of the coffee at a licensed warehouse, two licensed graders are selected, one each by the buyer and seller, and these men who are experts each receive at least three cents per bag for their services when performed for members of the exchange and at least six cents when for others. In case they disagree their differences are referred to the Board of Coffee Arbitrators, consisting of ten experts appointed by the board of managers. The superintendent now selects three of these arbitrators by lot. Upon examining approved samples of the coffee and comparing them with the standard samples, a majority decision of the arbitrators is final. Should they be unable to arrive at a decision from the samples submitted, the original graders are given an opportunity to alter their gradings, and if they do not do so the samples are submitted to the entire Board of Coffee Arbitrators, excluding any members who may have been the original graders, for a majority vote. As soon as the coffee is graded a certificate is issued stating the coffee grades and bearing the signatures of the superintendent and graders. This certificate is conclusive evidence of the grade for the subsequent six months, the buyer receiving the original and the seller a duplicate. 
In the course of trade, claims and trade controversies of various kinds occasionally arise, and the exchange organization includes machinery for their peaceful settlement. The board of managers annually elects an Arbitration Committee of five exchange members, who work under oath to decide disputes fairly. When the parties to a dispute submit their case to the committee they sign an agreement to abide by its decision. All parties, however, are not willing to arbitrate a dispute, and for such instances the board annually appoints an Adjudication Committee of seven. This committee has the power to adjudicate all claims and controversies between members arising out of any transaction in merchandise "if notice in writing of such claim or controversy, and of the intention to demand an adjudication thereon, be served by either party thereto within ten days from the ascertainment thereof." Within three days after such notice is served, each party either appoints an exchange member as his adjudicator or the superintendent does it for him, and these select a third from the adjudication committee. An appeal may, within two business days, be made to the board of managers, who, if they decide to grant the appeal, appoint an Appeal Committee of five not less than three of whom are members of the board. A majority vote of this committee then becomes final and binding. The difference between arbitration and adjudication of a dispute is that the former is voluntary with both parties, while the latter is compulsory upon application of one party.

Another committee of trade importance is the Spot Quotation Committee of five exchange members. Each day at two o'clock, except on Saturday, when it meets at 1I.45, this committee by a majority vote establishes the official daily market quotation of number seven coffee. There is likewise a Committee on Quotations of Futures. This committee of five meets daily "immediately after the first call and at the close of the exchange and reports to the superintendent the tone and price of the contract market, to be posted on the blackboard and transmitted to other exchanges and commercial bodies."

A Committee of five on Trade and Statistics has the important function of reporting to the board as to regulations for the "purchase, sale, transportation and custody of merchandise," and it attempts to establish uniformity in such matters between different markets. It also has charge of "all matters pertaining to the supply 
of newspapers, market reports, telegraphic and statistical information for the use of the exchange. In the early 80's the exchange abolished the old method of keeping coffee statistics, and the basis then adopted has since been accepted by all the large coffee markets of the world."

A Committee on Commissions (5) reports on changes in commissions, violations of the rules on commissions and the rules governing the employment of agents by exchange members. At present the minimum commission for members is two cents per bag, and for non-members it is four cents. In case of actual delivery an additional minimum brokerage of one cent for members and two cents for non-members prevails.

Other committees are the Finance Committee (2) to audit bills and claims against the exchange, direct deposits and investments, and audit the monthly and yearly accounts of the treasurer; a Law Committee (3), to deal with matters of legislation; a Committee on Rooms and Fixtures (3); Membership and Floor Committee (5); and a Nominating Committee (5). Organized as above outlined and with a well-established code of trade rules, the exchange annually transacts a large number of sales in a businesslike way. Since Igoo the volume of sales has varied from 6,88I,500 bags in 1908 to 25 , 487,500 in 1904. There is a large amount of trading in future contracts, and a standard form has been adopted by the exchange. No future contracts are valid unless they are made in the following form :

Sold for M.

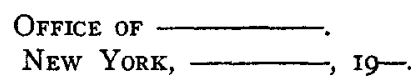

To M.

Thirty-two thousand five hundred pounds, or about 250 bags of coffee, growth of North, South or Central America, East or West Indies, deliverable from licensed warehouse in port of New York, between the first and last days of - next, inclusive. The delivery within such time to be at seller's option, upon a notice to buyer of either five, six, or seven days, as may be prescribed by the trade rules. The coffee to be of any grade, from No. 9 to to No. I, inclusive, provided the average grade shall not be below No. 8, at the rate of — cents per pound for No. 7, with additions or deductions for other grades according to the rates of the Coffee Exchange of the city of New York existing on the afternoon of the day previous to the date of the notice of delivery. Either party to have the right to call for margins as the 
variations of the market for like deliveries may warrant, which margins shall be kept good.

This contract is made in view of, and in all respects subject to, the rules and conditions established by the Coffee Exchange of the City of New York, and in full accordance with Section 102 of the by-laws.

(Across the face is the following:)

Brokers.

For and in consideration of one dollar to in hand paid, receipt whereof is hereby acknowledged, all its obligations and conditions.

All deliveries on such future contracts must be made from licensed warehouses. There is a separate "to arrive contract," but this likewise requires delivery at a licensed warehouse unless the buyer and seller have a mutual understanding to deliver the coffee from dock or ex-ship. Margins to protect the contract may be called for by either party. The largest deposit for margins was made in I904 when $\$ 22,661,7$ Io were deposited with the superintendent as required by the exchange rules.

The basis grade in a future sale is No. 7, but any other grade may be delivered so long as the average is not below No. 8. The price agreed upon is in terms of No. 7, and when other grades are delivered additions or deductions are made at a relative difference of $50 / 100$ of a cent per pound for each grade. This is a "fixed difference" plan not found in any of the great grain or cotton exchanges. At one time the trade followed the method of daily revisions, but the fixed difference plan was adopted as long ago as I884. About a decade later it was repealed, but has since been re-established. The secretary of the exchange believes that "the value of such fixed differences is manifest, as both buyer and seller know when entering into a transaction at what difference in price above or below the basis of all contracts, standard No. 7, coffee so bought or sold can be delivered." The right to deliver any grade in a future transaction has done much to avoid the danger of corners in the future market.

If no quantity of coffee is specified in a contract, it is understood to be for 250 bags of about I 32 pounds each. False or fictitious sales are prohibited, and all contracts must be reported to the superintendent. All contracts, moreover, are binding and call for the delivery of actual coffee, although "ring settlements" may 
be made whereby, as in a grain or cotton exchange, parties holding contracts against each other corresponding in all respects except as to price may cancel them after settling price differences.

The future contract, besides being used for the delivery of coffee during stated months in the future at a given price, is also used for hedging purposes. As in the grain or cotton markets, dealers protect themselves against price fluctuations by hedging in the future market. Importers, for instance, when purchasing coffee abroad frequently sell an equal amount for future delivery on the exchange. "When the time for delivery arrives it is simply a question of calculation of the market conditions whether it is more advantageous to repurchase the sales made as a hedge, or as a kind of insurance to protect themselves against loss, and free the coffee so engaged, or to make delivery of the coffee as it comes in."

The price of green coffee is largely determined on the exchanges of New York, Havre and Hamburg, and the daily quotations on the New York exchange are heeded by the coffee trade throughout the world. It is a natural market in that all the numerous price factors are weighed by the traders in making their transactions. The amount of production, the partial control of production and sales by the valorization plan, the growth or decline of coffee consumption, the adulteration of coffee, the use of coffee substitutes, such as tea, postum, malt coffee, etc., money and trade conditions, and trade expenses, all combine to make the price of coffee, but the exchange is the spot where the buyers and sellers, influenced by these various forces, meet each business day and trade in coffee. They bid and ask what they believe to be the possible price, but with each sale a buyer and seller come together and determine a definite price which becomes a matter of record. Price quotations are sent by one great market to another, and as each must heed to some extent those of the others, the trade, within certain limits determined by special conditions, obtains a world's price. As in the grain, cotton or any trade involving thousands of producers, traders and localities, only a highly organized market makes possible a world's price. Without it, differences in prices in different localities would be far wider than at present and the effect of supply and demand would be local instead of world wide.

' R. C. Auld, in The Alcolm Mag., March, 1909, p. 4.

(620) 